\title{
NORDISK PROSTITUSJONSPOLITIKK: SER VI FRAMVEKSTEN AV EN NORDISK MODELL?
}

Dr. May-Len Skilbrei Og dR. Charlotta Holmström

The prostitution policies implemented in the Nordic countries have gone through major changes over the past 15 years. A change that has drawn a lot of attention, both within the Nordic region and internationally, is the introduction of prohibitions against the purchase of sexual acts and services. Sweden, Norway and Iceland have introduced such prohibitions, and Finland has criminalised buying sex from victims of trafficking or persons involved in pimp-organised prostitution. The laws applied to prostitution have to be understood in light of how prostitution is defined and dealt with as a social problem, and their existence explained by ideological developments and developments in the prostitution market. The fact that several countries have implemented similar legal reforms does not mean that the Nordic countries have a consistent approach to prostitution. In this article we describe how prostitution is handled in the Nordic countries and discuss the question as to whether one can now say that there is a common Nordic prostitution regime. *

\section{Innledning}

Prostitusjonslovgivningen i Norden har gått gjennom store endringer de siste 15 årene. En etter en har de nordiske landene avkriminalisert det å tilby prostitusjon og å leve av prostitusjonsinntekter. Halliklovgivningen har blitt endret i flere av de nordiske landene etter hvert som markedet har endret seg: med opplevd vekst $\mathrm{i}$ innendørsprostitusjon kom fokus på å kriminalisere utleie av leilighet til prostitusjonsformål og annonsering på internett. Det er også blitt innført forbud mot menneskehandel $\mathrm{i}$ alle de nordiske landene, og det sterke fokuset på menneskehandel rammer nå inn alle debatter om prostitusjonspolitikk og prostitusjonsmarkedet. Den største endringen i prostitusjonslovgivningen, og den som vekker mest oppmerksomhet internasjonalt, er kriminaliseringen av det å kjøpe eller å forsøke å kjøpe seksuelle tjenester. I Sverige ble det forbudt å kjøpe seksuelle tjenester i 1999. Finland innførte et forbud mot å kjøpe sex av personer som er ofre for menneskehandel eller som jobber for en hallik i 2006. Norge innførte et fullt forbud mot kjøp av sex i 2009. Noen måneder etter fulgte Island etter og innførte et forbud mot sexkjøp. I Norden anno 2010 har altså alle land bortsett fra Danmark

\footnotetext{
Title in English: Nordic Prostitution Policies: Do We See the Emergence of a Nordic Model? Original in Norwegian.
} 
innført en eller annen form for kriminalisering av sexkjøp, samtidig som man har holdt det lovlig å selge sex. At flere av landene har gjennomført lignende rettslige reformer betyr likevel ikke at Norden har en enhetlig linje i forhold til prostitusjon, og i det følgende vil beskrive mer detaljert hvordan prostitusjon håndteres i de nordiske landene og diskutere spørsmålet om man nå kan si at det finnes en nordisk prostitusjonspolitisk modell.

\section{Den rettslige håndteringen av prostitusjon i Norden}

Kjøp av seksuelle tjenester ble kriminalisert i Sverige 1. januar 1999. Forbudet kom etter to tiår med debatt. Svenske myndigheter utga to offentlige utredninger om prostitusjon, en i 1981 og en i 1995, og spørsmålet om prostitusjon ble også diskutert i andre lovrevisjonsprosesser. I SOU 1995:15: Könshandeln ble det foreslått å kriminalisere både kjøpere og selgere av sex, en modell de fleste av høringsuttalelsene stilte seg negative til (Regeringens proposition 1997/98). Det endelige skrittet i retning av å kriminalisere bare kjøperne av sex ble tatt da temaet ble knyttet til en større lovreform rundt spørsmålet om seksualisert vold, oppsummert i SOU 1995:60: Kvinnofrid. Den svenske sexkjøpsloven bygger altså på SOU 1995:15 og Kvinnofrids-preposisjonen. Loven var for det første normativ, den var ment å endre holdninger til prostitusjon på lang sikt, men den skulle også påvirke størrelsen på prostitusjonsmarkedet. Loven var også ment å gi politikere og aktivister i andre land et verktøy i kampen for å kriminalisere kjøp av sex.

Mange har skrevet om hvorfor sexkjøpsloven ble innført (se for eksempel Gould 2001, Ekberg 2004, Kulick 2005, Träskman 2005, Svanström 2006 og Dodillet 2009). Selv om det er uenighet i hva som har vært utslagsgivende, er det tydelig $i$ alle disse analysene at det er nødvendig å ikke bare å se på den konkrete debatten i forkant, men også den større samfunnsmessige konteksten.

Spørsmålet om prostitusjon inngikk i en forståelse av at det svenske samfunnet ikke var kjønnslikestilt nok. Det ble lagt til grunn at prostitusjon ikke er frivillig, men skyldes strukturelle, kulturelle og personlige ulikheter og overgrep (Regeringskansliet 2002). Selv om prostitusjon forut for innføringen av loven ikke ble definert som en form for vold, er det klart at regjeringen så på prostitusjon "som nært knyttet til vold mot kvinner" (Dodillet 2009, SOU 2010:49). Senere har svenske myndigheter helt eksplisitt definert prostitusjon som menns vold mot kvinner (Regeringskansliet 2002). Kjønn har lenge vært den viktigste forklaringen på prostitusjon i Sverige, og dette har betydd at forskjeller mellom kvinner i vilkår i prostitusjon synes mindre viktig; det er som kvinner de gjøres til ofre for prostitusjon.

Spørsmålet om hvorvidt man skulle kriminalisere sexkjøp ble også debattert i de andre nordiske landene. I Finland ble dette debattert i flere år, og diskusjonene 
handlet i stor grad om prostitusjonen som involverte utenlandske kvinner. En arbeidsgruppe ble etablert for å utrede spørsmålet, og den konkluderte i 2003 med at kjøp av seksuelle tjenester burde kriminaliseres. Etter en høringsrunde ble saken lagt på is, før spørsmålet igjen kom opp i 2006 da det ble innført et forbud mot å kjøpe sex fra ofre for menneskehandel eller personer involvert $i$ hallikorganisert prostitusjon (Marttila 2008). Utviklingen av den finske debatten og praksis er nært knyttet til spørsmål om etnisitet og statsborgerskap. Dette er ikke overraskende i og med at det finske prostitusjonsmarkedet har vært påfallende internasjonalt siden begynnelsen av 1990-tallet. I og med at finske kvinners prostitusjon ikke på samme måte framsto som et problem, var den finske modellen nærliggende, nemlig å kriminalisere kjøp av sex i den prostitusjonen man fant mest problematisk.

I Norge har spørsmålet om kriminalisering blitt debattert flere ganger siden 1980-tallet, og en av disse debattene førte fram til at et forbud mot det å kjøpe seksuelle tjenester ble innført i 2009. Loven inneholder også et forbud mot kjøp av sex i utlandet for norske innbyggere. Påstander om effekten av den svenske sexkjøpsloven var viktige i den norske debatten, og det var også et opplevd problem med å finne gode måter å motarbeide menneskehandel på (Jahnsen 2008). Diskusjonene i Norge har hele tiden handlet om at selgerne er sårbare og at de har få muligheter til å velge noe annet enn prostitusjon, men det har variert hva man har vist til som årsak for denne sårbarheten. Kjønnsulikhet og kjønnsnormer har vært viktige forklaringer. I de tidlige diskusjonene var det et sterkt fokus på klasseforskjeller, og etter hvert ble det lagt mer og mer vekt på global ulikhet som årsak til prostitusjon (Jahnsen 2008). Økningen i utenlandske kvinner i prostitusjon i Norge vakte mye debatt, og dette innebar at det oppsto et press om å finne nye løsninger. Det er flere konkurrerende forlaringer på den norske kriminaliseringen, at det var et resultat av en langvarig innsats av feministiske organisasjoner (Håland \& Stø 2009), at det skyldes grasrotsinnsats innad i de politiske partiene (Bergstø 2009) eller at frykt for uønsket migrasjon påvirket hvilke metoder som ble sett på som egnede og hvilke argumenter som framsto som akseptable (Jahnsen 2008).

Bare fire måneder etter Norge, april 2009, ble det innført et generelt forbud mot kjøp av seksuelle tjenester på Island. Politikere og aktivister hadde jobbet for denne modellen i flere år, men selve innføringen av forbudet skjedde raskt og uten forarbeider (Atlason \& Gudmundsdottir 2008, Halldórsdóttir 2009). Island har også hatt tilbakevendende debatter om hvorvidt man skal kriminalisere kjøp av sex eller ikke, og også der var det svenske eksemplet sentral. Svensk debattanter har besøkt Island ved flere anledninger, og den feministiske organisasjonen Stigamót var en særlig aktiv deltaker i debatten, samt flere kvinnelige medlemmer av parlamentet (Atlason \& Gudmundsdottir 2008, Halldórsdóttir 2009).

I dag diskuteres et mulig forbud mot kjøp av seksuelle tjenester i Danmark 
og hvorvidt det blir flertall for dette ser ut til å være et åpent spørsmål. I Danmark synes det å være mye ambivalens til prostitusjon. Man hører både "liberale" argumenter om at prostitusjon hører privatsfæren til og argumenter om at prostitusjon som sådan er utnyttende og at all kjøp av sex bør gjøres straffbart (Lautrup 2002, Bjønness 2008). I det siste har imidlertid støtte for en kriminalisering for kjøp av sex vokst seg sterkere i Danmark, en utvikling Marlene Spanger (2008) ser i forhold til det økte antallet utenlandske kvinner i prostitusjon i Danmark.

Som nevnt innledningsvis, har det også skjedd flere andre lovendringer på prostitusjonsfeltet i de nordiske landene. Avkriminalisering av det å selge seksuelle tjenester er den viktigste av disse, selv om dette har vakt lite oppmerksomhet. Dette gjelder for eksempel avkriminalisering av måter å opprette kontakt med mulige kunder på, løsgjengeri og det å leve av prostitusjonsinntekter. Det siste landet til å avkriminaliserte salg av sex var Island som fjernet sitt forbud mot å leve av inntektene av prostitusjon i 2007.

Hallikvirksomhet er ulovlig i alle de nordiske landene og disse lovene blir ikke problematisert. Definisjonen av hallikvirksomhet har blitt endret i flere av de nordiske landene de siste 15 årene for å tilpasse dem markedsendringer som øt innendørsprostitusjon og økt betydning av annonser, og som en tilpasning til forbud mot menneskehandel. Det er noen forskjeller mellom de nordiske landene i hvordan grensene mellom ulike former for organisering og utnyttelse av prostitusjon er trukket.

I tillegg til forbud mot sexkjøp og hallikvirksomhet, griper de nordiske myndighetene inn i prostitusjon gjennom en rekke andre lover og bestemmelser. Selv om de overordnede nasjonale tilnærmingene definerer prostitusjon som kundens ansvar og skyld, finnes det andre sett med regler som tilsynelatende bygger på motsatte definisjoner. Et eksempel er bruken av utlendingsrett for å begrense prostitusjon. Personer som kommer utenfra EU/EØS for å selge sex i Danmark, Finland eller Sverige, altså tredjelandsborgere, kan bli stoppet og returnert ved grensen (Holmström \& Skilbrei 2008). Et annet eksempel på at andre lover enn generelle prostitusjonslover blir introdusert og aktivt brukt er fra Finland, hvor det ble innført en lov om offentlig orden som forbyr både å selge og kjøpe sex på offentlige steder i 2008 (Marttila 2008). Politikerne ønsket å innføre lignende lovgivning i Norge for å forhindre at personer som solgte sex gjorde det på ikke-ønskelige steder og på en ikke-ønskelig måte (Skilbrei 2009). Dette kan ses på som en del av en større europeisk utvikling i retning av å ha lav toleranse for lovlige, men ikkeønskbare handlinger i offentlig rom (Tani 2002). Med denne politikken gjør man både selgere og kjøpere ansvarlige for at det finnes prostitusjon. 


\section{Det ideologiske landskapet i Norden}

Prostitusjon har blitt definert som et sosialt problem i de nordiske landene siden slutten av 1970-tallet. Dette innebærer at det å redusere omfanget er et uttalt mål, og et premiss for diskusjoner om hvilken politikk man bør føre. Det varierer over tid og mellom landene hvorvidt man vektlegger individbaserte eller strukturelle forklaringer på prostitusjon. I Norge og Sverige ser vi et skifte i hvordan prostitusjon blir forklart på 1970- og -80-tallet, fra et fokus på individuelle problemer og fattigdom, til et fokus på klasse- og kjønnsbaserte ulikheter som viktigste årsaker til problemer og fattigdom, og derfor også til prostitusjon. I Sverige ble kjønn gitt en større betydning enn i Norge, der klasseperspektivet har vært sterkere. Selgeren blir på et generelt plan oppfattet som den i prostitusjonen med minst ressurser og med begrensede muligheter til å velge et annet liv (i f.eks Larsson \& Månsson 1979, Høigård og Finstad 1986). I Danmark har man i større grad holdt fast ved en individbasert forklaring på prostitusjon (Bjønness 2008), noe som kan skyldes at psykologi har spilt en viktigere rolle for utviklingen av kunnskap om prostitusjon enn for eksempel sosiologi (Balkmar et al. 2009).

Prostitusjonsmarkedet reguleres ikke av rettslige tiltak alene. I tillegg griper de nordiske statene inn i markedet gjennom sosiale tiltak. Disse arbeider i varierende grad etter en nullvisjon eller etter skadereduksjonsprinsipper (mer om dette, se Skilbrei og Renland 2008). Målrettende sosiale tiltak for selgerne i prostitusjonen ble startet opp i Norden på slutten av 1970-tallet. Som beskrevet over, så man mer og mer på prostitusjon som et problem som angikk myndighetene, blant annet fordi man antok at den som selger sex ikke gjør det frivillig, men heller bør ses som et offer for prostitusjon.

Utviklingen av målrettede sosiale tjenester startet i Sverige i 1977 da en det ble opprettet et prosjekt som skulle hjelpe kvinner ut av prostitusjon i Malmö (Månsson 1981). I samme periode ble de første sosiale tiltakene etablert i Norge, det første i forbindelse med bekymringer over ungdomsprostitusjon (Finstad et al. 1982). I Danmark ble Reden startet opp i København i 1983. Sosialt arbeid rettet mot personer som selger sex kan være utformet ulikt. Ulikheter i hvilke tjenester som prioriteres synes å reflektere forskjeller i tilnærmingen til prostitusjon og personer som er involvert i den. De sosiale tjenestene som tilbys i Sverige er i stor grad rettet mot å støtte kvinner (og menn) til å gå ut prostitusjon, noe som innebærer at de prioriterer rådgivning og terapi (SOU 2010:49), selv om dette bildet er mindre ensidig nå enn for få år siden. I Danmark, Finland og Norge har derimot sosialt arbeid rettet mot folk som selger sex hatt et eksplisitt et fokus på skadereduksjon, altså at man er opptatt av å lette hverdagen og å beskytte mot helseskader gjennom å dele ut kondomer og tilby lavterskel helsehjelp, heller enn å legge vekt på at klientene bør slutte med prostitusjon (Skilbrei og Renland 2008). 
De siste årene har det også kommet kommunale tiltak i Sverige som jobber etter skadereduksjonsmodellen (Holmström 2008). Dette kan man se på som et brudd på den generelle svenske tilnærmingen (som beskrevet i SOU 2010:49), og som en mer pragmatisk fundert tilnærming som finnes i nabolandene. Dette viser at $\mathrm{i}$ tillegg til at det er forskjeller mellom land i hvordan prostitusjon håndteres, er det forskjeller innad i de nordiske landene.

Et viktig trekk ved det sosiale arbeidet som har vokst fram de siste tretti årene er at disse organisasjonene har vært sentrale kunnskapsprodusenter, både fordi de utgir rapporter basert på arbeidet sitt og fordi de jobber tett med forskere. Dette samarbeidet har vært spesielt sterkt i Norge og Sverige, der sosialt arbeid og aksjonsforskning har gått hånd $\mathrm{i}$ hånd (se for eksempel Finstad et al. 1982). At sosiale tiltak er sentrale kunnskapsprodusenter er et viktig trekk ved den danske situasjonen, mens de andre landene i dag også har en del forskning (Bjønness 2008, Balkmar et al. 2009). Dette har hatt konsekvenser for den kunnskapen vi har om prostitusjon. Det har sørget for at kunnskapen er tett knyttet til behovene til personer som selger sex, men det betyr også at kunnskapen er begrenset til den delen av prostitusjonsmarkedet de sosiale tiltakene jobber opp mot. Dette har i overveiende grad har vært gateprostitusjon der kvinner selger sex til menn. Personer som selger sex og som av ulike grunner ikke oppsøker sosiale tiltak eller lar seg kontakte av disse, vet vi altså lite om. At den tilgjengelige kunnskapen, både fra sosiale tiltak og forskning, først og fremst har handlet om en begrenset del av prostitusjonsmarkedet har utvilsomt påvirket politikkdiskusjonene i de nordiske landene og det har betydd at fenomenet prostitusjon ser mye mer entydig ut enn det er (Pettersson \& Tiby 2003). Selv om kunnskapsproduksjonen også i Danmark hovedsaklig utføres av eller foregår i tett samarbeid med sosiale tiltak, er det mer kunnskap om innendørsprostitusjonen der (se for eksempel Pedersen \& Heindorf 2000, Christensen \& Barlach 2004). Kunnskap om menns prostitusjon i de nordiske landene er spesielt mangelfull. Menns prostitusjon blir ikke behandlet som et problem på samme måte som kvinners (Siring 2008), og dette påvirker både hvordan prostitusjonslovgivningen brukes og sosiale tiltak utformes.

\section{Forholdet mellom prostitusjonspolitikk og prostitusjonsmarked}

De nordiske myndighetene griper aktiv inn i prostitusjonen, både med lovgiving og sosiale tiltak. De siste tiårenes diskusjoner om prostitusjonspolitikk henger sammen med opplevde endringer i markedet. På 1990-tallet handlet det om å tilpasse lovene forskyvninger mellom innendørsprostitusjon og gateprostitusjon, blant annet fordi teknologiske nyvinninger som mobiltelefoni og internett gjorde gateprostitusjonen mindre viktig. Også siden har innendørsarenaene blitt mer og mer viktige (Rasmussen 2007, Socialstyrelsen 2007, Marttila 2008). 
Diskusjonene om kundekriminalisering har også handlet om det man mener er utviklingen eller hvordan man frykter at utviklingen vil bli. De nordiske prostitusjonsmarkedene har i økende grad inkludert selgere fra andre land (Holmström og Skilbrei 2008). Økende internasjonalisering av prostitusjonsmarkeder ble trukket inn i de svenske kriminaliseringsdiskusjonene (Kulick 2005), selv om det svenske markedet på daværende tidspunkt først og fremst inkluderte svenske borgere. I Finland har utenlandske personers prostitusjon vakt mye oppmerksomhet og man diskuterte kriminalisering for å forhindre at dette økte ytterligere. Da kriminalisering ble innført i Norge i 2009 kom det etter langvarige diskusjoner hvor det å forhindre utenlandske borgeres prostitusjon og menneskehandel var de mest sentrale argumentene (Jahnsen 2008). Siste land ut, Island, har lite påvist prostitusjon, selv om politikere og aktivister peker på muligheten til at strippebarer der utenlandske kvinner arbeider i realiteten er bordeller (Atlason \& Gudmundsdottir 2008).

Siden sexkjøpsloven ble innført i Sverige har det vært delte meninger om hvorvidt loven har ført til redusert omfang av prostitusjon. Størrelsen på det svenske prostitusjonsmarkedet ble ansett som lite i forhold til andre europeiske land før loven ble innført (Regeringens proposition 1997/98), og en evaluering av loven i 2010 konkluderer de samme 11 år etter (SOU 2010:49). Evalueringen konkluderte med at loven har hatt den ønskede effekten, og dette har mottatt en del kritikk i svensk offentlighet. Utredningen er kritisert for ikke å redegjøre godt nok for kunnskapsgrunnlaget og for å konkludere på et for svakt grunnlag (se for eksempel Agustín \& Persson 2010). I de andre nordiske landene har myndighetene så langt ikke konkludert med at lovene har hatt en direkte effekt på størrelsen på prostitusjonsmarkedet eller omfanget menneskehandel. I Norge har medierapporter siden loven kom både vist til nedgang og opprettholdelse av samme nivå som før loven, men de fleste vil være enig $\mathrm{i}$ at det er for tidlig å konkludere.

Forholdet mellom utviklingen av nordisk prostitusjonspolitikk og nordiske prostitusjonsmarkeder har vakt mye oppmerksomhet både i Norden og internasjonalt. Kunnskapen om utvikling av denne politikken og disse markedene er ujevn og lite systematisk, slik det påpekes i SOU 2010:49, og dette er et problem i og med at denne kunnskapen trekkes inn i utformingen av andre lands prostitusjonspolitikk.

\section{Finnes det en nordisk prostitusjonsmodell?}

Det er noen viktige likhetstrekk mellom de nordiske landene i hvordan man forstår og griper inn i fenomenet prostitusjon. Over en periode på 10 år har ideen om å bekjempe prostitusjon gjennom å fokusere på sexkjøperne vunnet terreng i fire av fem nordiske land. Men disse lovene er innført av ulike grunner og basert på ulike virkelighetsforståelser. I tillegg reguleres prostitusjon også av en rekke andre lover og regler hvor ansvaret for prostitusjon, gjerne når det er snakk om utenland- 
ske kvinner, legges hos selgerne av sex, ikke kjøperne. I tillegg er det forskjeller i utformingen av sosiale tiltak som innebærer at landene kombinerer lovgivning og sosialt arbeid på ulik måte. Likevel kan fokuset på det sosiale arbeidet forstås som et spesifikt nordisk utviklingstrekk. Det kan også framveksten av empirinær og samfunnskritisk samfunnsforskning i tett samarbeid med sosialt arbeid. Det er også forskjeller mellom landene i hva ved prostitusjonen som framstilles som problemet; om det er kjønn og forholdet mellom menn og kvinner som er det som sier oss mest om prostitusjon, eller om hvordan prostitusjon erfares og reguleres handler mest om etnisitet eller nasjonalitet. Ut fra dette håndteres prostitusjon og partene i den i dag ulikt avhengig av hvem som er selgeren. Menns prostitusjon forblir usynlig i Sverige hvor prostitusjon defineres som menns vold mot kvinner. Og finske, norske, islandske og danske personers prostitusjon blir usynlig eller irrelevant når utenlandsk prostitusjon defineres som problemet. Prostitusjonsmarkedene i de nordiske landene er mer differensierte nå enn tidligere, både fordi prostitusjon foregår på flere arenaer og fordi de som er involverte kommer fra mange ulike land og har ulike vilkår. Dette er en utfordring for den rettslige og sosiale håndteringen av prostitusjon, fordi man i utviklingen av tiltak har forutsatt stor grad av likhet. Det varierer hvorvidt man klarer å håndtere de store forskjellene vi ser i dag mellom personer som selger sex, men det er klart at dette har vært en utfordring i hele Norden.

For å få forstå kompleksiteten i utviklingen av prostitusjonspolitikk må den plasseres i en bred ramme og sammenlignes med andre politikkområder, ikke bare forstås i lys av den historiske utviklingen av prostitusjonspolitikk. Den økende interessen for og fokus på kunden må både knyttes til politiske og sosiale endringer fra 1970-tallet av, og til globalisering og frykt for endrede prostitusjonsmarkeder, uønsket migrasjon og menneskehandel. Modeller for prostitusjonspolitikk skjuler ofte forskjeller som de vi har identifisert i Norden, mellom ideologiske og praktiske argumenter, i hvilke former for ulikhet som gis forrang og hvilke former for prostitusjon man i størst grad definerer som problemet. Ulike modeller for statlig inngripen i prostitusjon har blitt utviklet av forskere, hvor man lager et skille mellom for eksempel forbudslinjen, toleranse, legalisering og avkriminalisering (Westmarland \& Gangoli 2006), eller mellom en abolisjonistisk og en liberalistisk modell (se f.eks Thorbek 2002). De nordiske landenes politikk kan ikke entydig forstås som abolisjonistisk fordi man har valgt å kriminalisere bare den ene parten selv om prostitusjon kan bekjempes enda mer om begge parters handlingen var kriminalisert. Vi vil hevde at de forskjellene vi viser til i de nordiske landenes tilnærming til prostitusjon, både $\mathrm{i}$ argumenter for lovene, i hvordan lovene håndheves, i hvordan den rettslige tilnærmingen kobles til sosialt arbeid og i hvordan man håndter forskjeller innad i prostitusjonen, er så store at det ikke er fruktbart 
å forstå de nordiske landenes prostitusjonspolitikk som noe som utgjør en felles modell eller regime.

\section{Referanser}

Agustín, L. og Persson L. (2010). 'Tvivelaktig rapport om sexköp', Svenska Dagbladet 15.07 .10 .

Atlason, G. H. og Gudmunsdottír, K. A. (2008) 'Prostitution og kvindehandel i Island'. I C. Holmström og M-L. Skilbrei (red.) Prostitution i Norden. TemaNord 2008:604, København: Nordisk Ministerråd, s. 183-208.

Balkmar, D., Iovanni, LA. og Pringle, K. (2009), 'A Reconsideration of Two "Welfare Paradises": Researh and Policy Responses to Men's Violence in Denmark and Sweden', Men and Masculinities 12(2): 155-174.

Bergstø, K. (2009) 'Kampen om et regjeringsparti'. I T. R. Korsvik og A. Stø (red.) Nei til kjøp av sex og kropp! Feminister skriver usensurert om den nordiske kampen for å forby sexkjøp. Oslo: Kolofon Forlag, s. 96-104.

Bjønness, J. (2008), 'Sociale tiltag som vidensproducent: Om sociale tiltag og erfaringsbaseret viden på prostitutionsfeltet i Danmark efter 1990'. I C. Holmström og M-L. Skilbrei (red.). Prostitution i Norden. TemaNord 2008:604, København: Nordisk Ministerråd, s. 43-66.

Christensen, G. og Barlach, L. (2004). Prostitution på massageklinikker. En spørgeskemaundersøgelse om kvinder, der prostituerer sig på massageklinikker. København: VFC Socialt Udsatte.

Dodillet, S. (2009). Är sex arbete? Svensk och tysk prostitutionspolitik sedan 1970-talet. Stockholm: Vertigo forlag.

Ekberg, G. (2004): 'The Swedish Law that Prohibits the Purchase of Sexual Services: Best Practices for Prevention of Prostitution and Trafficking in Human Beings', Violence Against Women 10 (10): 1187-1218.

Finstad, L., Fougner L. og Holter, V-A. (1982). Prostitusjon i Oslo. Oslo: Pax Forlag.

Gould, A. (2001). 'The Criminalisation of Buying Sex: the Politics of Prostitution in Sweden', Journal of Social Policy 30(3):437-456.

Halldórsdóttir, K. (2009), 'Kampen for kriminalisering af sexköb - en kampsaga fra Island'. I T. R. Korsvik og A. Stø (red.): Nei til kjøp av sex og kropp! Feminister skriver usensurert om den nordiske kampen for å forby sexkjøp. Oslo: Kolofon Forlag, s.105-120.

Holmström, C. (2008), 'Prostitution och människohandel för sexuella ändamål i Sverige: omfattning, förekomst och kunskapsproduktion'. I C. Holmström og M-L. Skilbrei (red.). Prostitution i Norden. TemaNord 2008:604, København: Nordisk Ministerråd, s. 303-326. 
Høigård, C. og Finstad, L. (1986). Bakgater: Prostitusjon, penger og kjarlighet, Pax: Oslo.

Håland, A. og Stø, A. (2009) 'En grasrothistorie'. I T. R. Korsvik og A. Stø (red.). Nei til kjøp av sex og kropp! Feminister skriver usensurert om den nordiske kampen for å forby sexkjøp, Oslo: Kolofon Forlag, s. 35-50.

Jahnsen, S. (2008), 'Norge er ikke en øy'. I C. Holmström og M-L. Skilbrei (red). Prostitution i Norden: Forskningsrapport. København: Nordisk Ministerråd, s. $255-276$.

Kulick, D. (2005), 'Four hundred thousand Swedish perverts', GLQ 11(2): 20535 .

Larsson, S. og Månsson, S-A. (1979) Könshandeln, en studie i klass- och kvinnoförtryck, Lund: Sociologiska institutionen, Lunds universitet, upublisert manuskript.

Lautrup, C. (2002): Unge i prostitution og lovgivning - Evaluering af Straffelovens $\S 223 a$, Copenhagen: PRO-Centret.

Marttila, A-M. (2008). 'Transnationell prostitution och gränser för välfärd i Finland'. I Holmström, L. og Skilbrei, M-L. (red.). Prostitution i Norden, TemaNord 2008:604, København: Nordisk Ministerråd, s. 123-150.

Månsson, S-A. (1981). Könshandelns främjare och profitörer. Om förhållandet mellan hallick och prostituerad. Karlshamn: Doxa.

Paasonen, S. (2009), 'Healthy Sex and Pop Porn: Pornography and the Finnish Context', Sexualities 12(5): 586-60g4.

Pedersen, F. H. og Heindorf, J. (2000). Barprostitution? En kortloegning af 14 strip-barer i København,København: PRO-Centret.

Pettersson, T. og Tiby, E. (2003), 'The production and reproduction of prostitution', Journal of Scandinavian Studies in Criminology and Crime Prevention $3(2): 154-172$

Rasmussen, N. (2007). Prostitution i Danmark, København: Servicestyrelsen.

Regeringens proposition 1997/98:55: Kvinnofrid

Regeringskansliet (2002): Prostitution och handel med kvinnor, Faktablad, Stockholm: Näringsdepartementet.

Regeringskansliet (2005): En ny sexualbrottslagstiftning, Faktablad, Stockholm: Justitiedepartementet

Siring, A. (2008), 'Sexhandel, sexköpslagstiftning och myndighetsförståelse. Ett svenskt exempel'. I C. Holmström og M-L. Skilbrei (red.). Prostitution i Norden, TemaNord 2008:604, København: Nordisk Ministerråd, s. 327-356.

Skilbrei, M-L. og Renland, A. (2008), ' $\AA$ tolerere eller ikke å tolerere, det er spørsmålet: Forholdet mellom lovgivning og sosialt arbeid på prostitusjonsfeltet', Tidsskrift for velferdsforskning 11(3): 166-178. 
Skilbrei, M-L. (2009), 'Nigeriansk prostitusjon på norsk: Feil kvinner på feil sted'.

I W. Mühleisen og A. Røthing (red.) Norske seksualiteter, Oslo: Cappelen Akademisk Forlag, s. 165-184.

Socialstyrelsen (2007). Kännedom om prostitution 2007, Stockholm.

SOU 1995:60: Kvinnofrid.

SOU 2010:49: Förbud mot köp av sexuell tjänst. En utvärdering 1999-2008.

Spanger, M. (2008), 'Socialpolitiske tiltag og feministisk gennemslagskraft? Trafficking som policy felt i Danmark'. I C. Holmström og M-L. Skilbrei (red.): Prostitution i Norden, TemaNord 2008:604, København: Nordisk Ministerråd, s. 67-100.

Svanström. Y. (2006), 'Prostitution in Sweden: debates and policies 1980-2004'. I G. Gangoli og N. Westmarland (red.). International Approaches to Prostitution: Law and policy in Europe and Asia. Bristol: Policy Press, s. 67-90

Tani, S. (2002), 'Whose Place is this Space? Life in the Street Prostitution Area of Helsinki, Finland', International Journal of Urban and Regional Research 26(2): 343-359.

Thorbek, S. (2002), 'Introduction: Prostitution in a Global Context: Changing Patterns'. I S. Thorbek og B. Pattanaik (red.): Transnational Prostitution. Changing Global Patterns, London: Zed Books, s. 1-10.

Träskman, P. O. (2005), "'Den som betalar för sex är en brottsling" - Om den svenska kriminaliseringen av sexköp som ett medel för att motverka prostitutionen', Nordisk Tidsskrift for Kriminalvidenskab 92(1): 73-92.

Westmarland, N. \& Gangoli, G. (2006), 'Introduction: approaches to prostitution'. I G. Gangoli og N. Westmarland (red). International Approaches to Prostitution: Law and policy in Europe and Asia. Bristol: Policy Press, s. 1-20.

May-Len Skilbrei

Fafo Institutt for anvendte internasjonale studier

Postboks 2947 Tøyen

0608 Oslo

Norge

e-post: $\underline{\text { mls@fafo.no }}$

Charlotta Holmström

Malmö högskola

Fakulteten för Hälsa och samhälle

20506 Malmö

Sverige

e-post: charlotta.holmstrom@mah.se 